\begin{tabular}{|} 
Ambiente \& Água - An Interdisciplinary Journal of Applied Science \\
ISSN 1980-993X - doi:10.4136/1980-993X \\
www.ambi-agua.net \\
E-mail: ambi.agua@gmail.com
\end{tabular}

\title{
Growth and special structures production of Nostoc paludosum (Nostocaceae, Cyanobacteria) under nutrient starvation and different light intensities
}

\author{
ARTICLES doi:10.4136/ambi-agua.2191 \\ Received: 02 Oct. 2017; Accepted: 12 Oct. 2018
Rafael Barty Dextro ${ }^{*}$; Fellipe Henrique Martins Moutinho²; Cristina Souza Freire Nordi ${ }^{2}$

\begin{abstract}
${ }^{1}$ Universidade Federal de São Carlos (UFSCar), São Carlos, SP, Brasil Departamento de Botânica (DB). E-mail: rafaelbarty@yahoo.com.br

${ }^{2}$ Universidade Federal de São Paulo (UNIFESP), São Paulo, SP, Brasil Departamento de Ecologia (DE).E-mail: fhm.moutinho@gmail.com, cris_nordi@hotmail.com

*Corresponding author
\end{abstract}

\begin{abstract}
The effects of the absence of nitrogen and phosphorus on AA media and three different light intensities (100\% Light, $60.0 \pm 2.7 \mu \mathrm{mol} \mathrm{m}^{-2} \mathrm{~s}^{-1}, 50 \%$ Light, $30.0 \pm 2.7 \mu \mathrm{mol} \mathrm{m}^{-2} \mathrm{~s}^{-1}$, and $13.5 \%$ Light, $8.1 \pm 2.7 \mu \mathrm{mol} \mathrm{m}^{-2} \mathrm{~s}^{-1}$ ) on cell production and synthesis of heterocytes and akinetes were determined in a strain of Nostoc paludosum. In the experiment concerning the absence of nutrients, significant variations were observed between the control group and the groups with absence of nutrients, especially in cell numbers and in synthesis of heterocytes and akinetes. The absence of nitrogen boosted the formation of heterocytes and the absence of phosphorus produced the most akinetes. As for the different light conditions, the growth curves determined for each treatment showed that cell synthesis is slightly affected by the reduction of illuminance. The different light intensities are capable of reducing the maximum growth rates of Nostoc paludosum, with $13.5 \%$ light restriction being the most effective on limiting the cell growth rate and inducing the formation of akinetes. The synthesis of heterocyte does not seem directly correlated to light intensity, being better explained by nutritional factors. The data found contributes to the understanding of some of the factors involving growth and synthesis of special structures in Nostoc paludosum.
\end{abstract}

Keywords: Limnology, microbiology, nostocales.

\section{Crescimento e produção de estruturas especiais em Nostoc palusodum (Nostocaceae, Cyanobacteria) sob limitação nutricional e diferentes intensidades luminosas}

\section{RESUMO}

O efeito da ausência de nitrogênio e fósforo em meio AA e de três diferentes intensidades luminosas (100\% Luz, $60.0 \pm 2.7 \mu \mathrm{mol} \mathrm{m}^{-2} \mathrm{~s}^{-1}, 50 \% \mathrm{Luz}, 30.0 \pm 2.7 \mu \mathrm{mol} \mathrm{m} \mathrm{m}^{-2} \mathrm{~s}^{-1}$, e $13.5 \% \mathrm{Luz}$, $\left.8.1 \pm 2.7 \mu \mathrm{mol} \mathrm{m} \mathrm{m}^{-2} \mathrm{~s}^{-1}\right)$ sobre a quantidade de células e síntese de heterócitos e acinetos foi determinada em uma cepa de Nostoc paludosum. No experimento de limitação nutricional, 
variações significantes foram observadas entre o grupo controle e os grupos com ausência de um nutriente, especialmente em relação ao número de células e na síntese de heterócitos e acinetos. A ausência de nitrogênio induziu a formação de heterócitos e a falta de fósforo produziu a maior quantidade de acinetos. Para as diferentes condições luminosas, as curvas de crescimento de cada tratamento mostraram que a síntese celular é afetada pela redução de luminosidade. As diferentes intensidades de luz são capazes de alterar a taxa máxima de crescimento de Nostoc paludosum, sendo o grupo de $13.5 \%$ de luz o mais afetado e no qual há maior formação de acinetos. A síntese de heterócitos não parece ter relação direta com a intensidade luminosa, sendo melhor explicada pelos fatores nutricionais. Os resultados obtidos contribuem para a compreensão de fatores envolvendo o crescimento e a síntese de estruturas especiais em Nostoc paludosum.

Palavras-chave: limnologia, microbiologia, nostocales.

\section{INTRODUCTION}

Cyanobacteria are frequently a dominant group of primary producers in freshwaters, especially reservoirs, lakes and waters retained by dams. In Brazil, these water bodies are generally shallow and with a long residence time, generating advantageous conditions for the development and dominance of cyanobacteria (Sant'Anna et al., 2007). It is well known that these water bodies can be directly affected by human activities, reaching a eutrophic state in which there is an increase of nutrient concentrations, especially phosphorus and nitrogen.

Some cyanobacteria, such as the genera Dolichospermum, Anabaena and Nostoc, possess morphological plasticity in the vegetative cells that form the trichomes, a reflection of differential gene expression (Lyra et al., 2001), allowing them to alter cellular structures in order to form akinetes and heterocytes, which are highly specific cells.

Akinetes are specialized cells, generated from vegetative cells, which have thickened cell walls and can store large amounts of reserve substances (Braune, 1980). The akinetes play an important role in cyanobacterial reproduction, also acting as a resistant cell that can remain dormant in the sediment when environmental conditions are unfavorable.

Heterocytes are also specialized cells present in some filamentous cyanobacteria that give them the capacity to fix atmospheric nitrogen under light. They are different from the other vegetative cells because of their thick cell walls, pores in each of their extremities and different cytoplasm organization (Haselkorn et al., 1993). Through these pores, selective exchanges of materials occur with neighboring cells.

The alteration of the nutrient composition in the growth media has been explored by several studies, using different species of organisms. In Healey and Hendzel (1979), five species of freshwater algae are submitted to various degrees of nitrogen $(\mathrm{N})$ and phosphorus $(\mathrm{P})$ limitation. Their analyses was focused on metabolic activity, with little to no evaluation of the algae's morphologies.

The evaluation of the effects of the removal of specific nutrients is also commonly found in the literature. One of the most-studied nutrients is nitrogen, since its removal causes great alterations in growth patterns and can induce the formation of special structures in some species of cyanobacteria (Healey and Hendzel, 1979; Haselkorn et al., 1993; Nalewajko and Murphy, 2001 and Zapomělová et al., 2008b). Other focus nutrients studied include zinc, phosphorus and copper due their physiological and environmental significance.

Light intensity is a very important factor in microorganisms' cultivation. Each species normally presents a range of optimal illuminance associated with their photosynthetic apparatus. An excess or reduction of light can severely alter cell morphology and the cyanobacteria's growth pattern (Tonk et al., 2005). 
Because of the occurrence of blooms associated with the production of toxins and unpleasant taste and odor in freshwater, studies of cyanobacteria control and monitoring in reservoirs, which provide drinkable water for millions of people in major cities, can prevent serious environment and public health problems. A detailed understanding of the production of akinetes and heterocytes is crucially important for the future control of these cyanobacteria populations in natural environments. There are many researchers evaluating how these structures are produced and the factors involved in their synthesis, especially the aspects that trigger their formation. The majority of the recent studies are done using the Dolichospermum, Anabaena and Cylindrospermopsis genera (Zapomělová et al., 2008a; 2008b), which are more abundant and dominant in natural environments. Nevertheless, studies using other cyanobacteria as models are just as important to provide a wider spectrum of how akinetes and heterocytes are linked with these organisms' biology.

Apart from its ecological role as a member of the phytoplankton, the species Nostoc paludosum Kützing ex Bornet and Flahault 1888 is currently being used or shows potential to be used in various applications: antibiotic production, phycobiliprotein-pigment extraction, fatty acid production and agricultural use in root nodules (Temina et al., 2007; Pankratova et al., 2008). However, there has been little research concerning its biology and none evaluating its reaction to different growth conditions. The main purpose of this study was to monitor the morphological changes that occur in trichomes by quantifying vegetative cells, akinetes and heterocytes of Nostoc paludosum during different phases of growth in laboratory-controlled conditions.

\section{MATERIALS AND METHODS}

The inoculum of Noctoc paludosum used in these experiments was provided by Dr. Armando Augusto Henriques Vieira from the algae bank of the Botany Department of UFSCAR/ São Carlos Campus (strain 145). This particular strain was collected from the Monjolinho pond, from a preserved cerrado area in the city of São Carlos. In the natural habitat, this strain presented an epiphytic habit, which is characteristic for the genus Nostoc. All the samples were maintained in AA medium (Allen and Arnon, 1955) and in controlled temperature conditions $\left(25 \pm 1^{\circ} \mathrm{C}\right)$ and light/dark cycle $(12 \mathrm{~h}: 12 \mathrm{~h})$ in a greenhouse (ElectroLab $®$, Model EL202/4) with maximum internal luminous intensity of $175 \mu \mathrm{mol} \mathrm{m}^{-2} \mathrm{~s}^{-1}$ produced by white fluorescent lights.

\subsection{General methodology}

All cultures were grown in an axenic state and in Mariotte's bottles because their inferior exit makes it easier for samples to be taken. All the manipulation done to the culture bottles was done in a laminar flow chamber. The inoculums were allowed to grow for 5 days in AA medium prior to the experiments. An equal sample for all groups was taken and transferred to the Mariotte's bottles for each experimental group and their replicates, totaling 3 bottles for each experimental condition. The total duration of the experiment was 30 days, with sampling being done daily until day 10; afterwards, it was done every other day until the end of the experiment. The samples taken contained the same volume $(3 \mathrm{~mL})$, and lugol $(1 \%)$ was used to fix them as soon as they were removed.

\subsection{Morphological Evaluation}

The morphology of the cells, the cell number and the production of akinetes and heterocytes in each sample were analyzed and counted daily using a Labomed 400x optical microscope. The number of cells, heterocytes and akinetes were observed in a Sedwick-Rafter counting chamber using the score from 50 squares in horizontal and vertical transects. The following confidence interval Equation 1 was applied after 50 squares were counted:

\section{IPABH}

Rev. Ambient. Água vol. 13 n. 6, e2191 - Taubaté 2018 
$A=t_{n} \sqrt{\frac{X \cdot(N-n)}{(N \cdot n)}}$

Being:

A - count error;

$\mathrm{X}$ - total cell number found divided by number of squares counted;

$\mathrm{t}$ - t-test (n-1), using 0.05 as significance level;

$\mathrm{N}$ - total squares on the Sedwick-Rafter chamber $(\mathrm{N}=1000)$;

$\mathrm{n}$ - number of squares counted.

After each application of the test, the number of cells was only accepted if it produced a count error of $25 \%$ or less. When the error passed this limit, 10 additional squares were counted and the equation was reapplied until the results were within desired maximum error. After the counting was done for all the samples, an average of each group resulted in a final number of average cell production, average heterocytes and average akinetes per day. This data was used to produce the growth curves and the special structures synthesis graphs.

Measurements were also performed for each experimental group on days 5, 10 and 20. A hundred vegetative cells, heterocytes and akinetes were measured for each bottle each day. The measured cells were selected randomly and they could not belong to the same trichome. An ANOVA test (Excel 2013) was used to determine the statistical significance of the size variation observed between treatments. During the measurements, the positioning of the heterocytes and akinetes along the trichome was recorded.

\subsection{Absence of Nitrogen and Phosphorus Experiment}

Modified AA medium was used in two different formulations: the first without nitrogen source (ammonium metavanadate) and the other without phosphorus (lacking potassium phosphate). A third treatment was used as a control, containing the original AA medium, and all of these treatments were done with triplicates. The nutrient-absent media had their $\mathrm{pH}$ corrected to a value similar to that of the regular AA medium used in the control group (approximately 6.85). All treatments were exposed to the same light intensity of approximately $120.0 \pm 0.9 \mu \mathrm{mol} \mathrm{m} \mathrm{m}^{-2} \mathrm{~s}^{-1}$, measured inside the bottles with culture media. To ensure that no bottle was favored, their positions were daily switched inside the greenhouse. The experiment duration was 29 days, with daily samples taken as explained in the General Methodology section. The initial inoculum for each treatment was kept the same, at approximately $1.00 \times 10^{5}$ cells per $\mathrm{mL}^{-1}$. The data gathered permitted the construction of growth curves and the bar graphs representing the production of the specialized cells (akinetes and heterocytes) using Igor Pro 6.3 software. The number of cells per day was obtained by calculating the average value between all three replicates of each treatment. Standard deviation of each day was also calculated. The maximum specific growth rates per day $\left(\mu_{\max } /\right.$ day $)$ were calculated by linear fitting of $\ln$ values of growth curve in $\log$ phase and were used to determine the duplication time during log phase. Apart from cell number and akinete/heterocyte productions, the shape, size and position of cells and specialized cells was also evaluated, as was trichome fragmentation and number of heterocytes per trichome.

\subsection{Light Experiment}

The three light conditions evaluated were: total light intensity $(100 \%$ light $=60.0 \pm$ $\left.2.7 \mu \mathrm{mol} \mathrm{m} \mathrm{m}^{-2} \mathrm{~s}^{-1}\right)$; partial light intensity $\left(50 \%\right.$ light $=30.0 \pm 2.7 \mu \mathrm{mol} \mathrm{m}^{-2} \mathrm{~s}^{-1}$, obtained with the effect of covering the Mariotte's bottle with black tulle fabric); and restricted light intensity 
$\left(13.5 \%\right.$ light $=8.1 \pm 2.7 \mu \mathrm{mol} \mathrm{m} \mathrm{m}^{-2} \mathrm{~s}^{-1}$, obtained with the effect of covering the Mariotte's bottle with black TNT fabric). All of these treatments were done with triplicates. The light measurements were done with a manual and portable light meter and these light intensities were determined inside the bottles with culture media. To ensure that no bottle was favored, their positions were daily switched inside the greenhouse. All conditions were maintained in AA medium, with the total light intensity treatment used as a control. The experiment duration was 30 days, with daily samples taken as explained in the General Methodology section. The initial inoculum for each treatment was kept the same, at approximately $2.50 \times 10^{6}$ cells per $\mathrm{mL}^{-1}$. The data gathered permitted the construction of growth curves and the bar graphs representing the production of the specialized cells (akinetes and heterocytes) using Igor Pro 6.3 software. The number of cells per day was obtained by calculating the average value between all three replicates of each treatment. The standard deviation for each day was also calculated. The maximum specific growth rates per day $\left(\mu_{\max } /\right.$ day) were calculated by linear fitting of $\ln$ values of the growth curve in the log phase and were used to determine the duplication time during the log phase. Apart from the cell number and akinete/heterocyte production, the shape, size and position of cells and specialized cells was also evaluated, as was trichome fragmentation and the number of heterocytes per trichome.

\section{RESULTS AND DISCUSSION}

\subsection{Absence of Nitrogen and Phosphorus Experiment}

Growth curves using the average number of total cells counted for each treatment were produced for the first experiment (Figure 1). A growth curve displaying only the log and stationary phases was obtained for the control group, whereas the nitrogen-absent and phosphorus-absent groups displayed a different pattern, with a slight drop after the stationary phase.

The control group showed a considerably larger number of cells when compared to the other two groups, which produced an average of 100 times less cells than the control. As for the maximum specific growth rate of each treatment, the control showed the highest value when compared to the other treatments $\left(\mu_{\max }=0.814\right.$ day $^{-1}$ for the control, $\mu_{\max }=0.598$ day $^{-1}$ for nitrogen-absent and $\mu_{\max }=0.592$ day $^{-1}$ for phosphorus-absent). The control group duplication time was 5 hours ( $299 \pm 12$ minutes), much lower than the duplication time exhibited in the nitrogen-absent group (14 hours or $842 \pm 7$ minutes) and in the phosphorus-absent group (13 hours or $785 \pm 11$ minutes).

Although the heterocyte synthesis followed a similar pattern in the nutrient-absent groups, the quantities were significantly higher in the nitrogen-absent group throughout the experiment (Figure 2A). The control group presented the smallest values for heterocytes per cell among all groups and during throughout the experiment. The synthesis of heterocytes in the nutrientabsent groups peaked during the log phase, in the beginning of the experiment, then increased continuously after the eighth day of experiment, with the highest value observed at the end of the experiment (at day 20).

The presence of akinetes was only considerably noticeable at the end of the experiment (Figure 2B), with the highest frequency occurring in the phosphorus-starved group on the last day of the experiment $\left(0.0361\right.$ akinete per cell or 16,360 akinetes $\left.\mathrm{mL}^{-1}\right)$. 


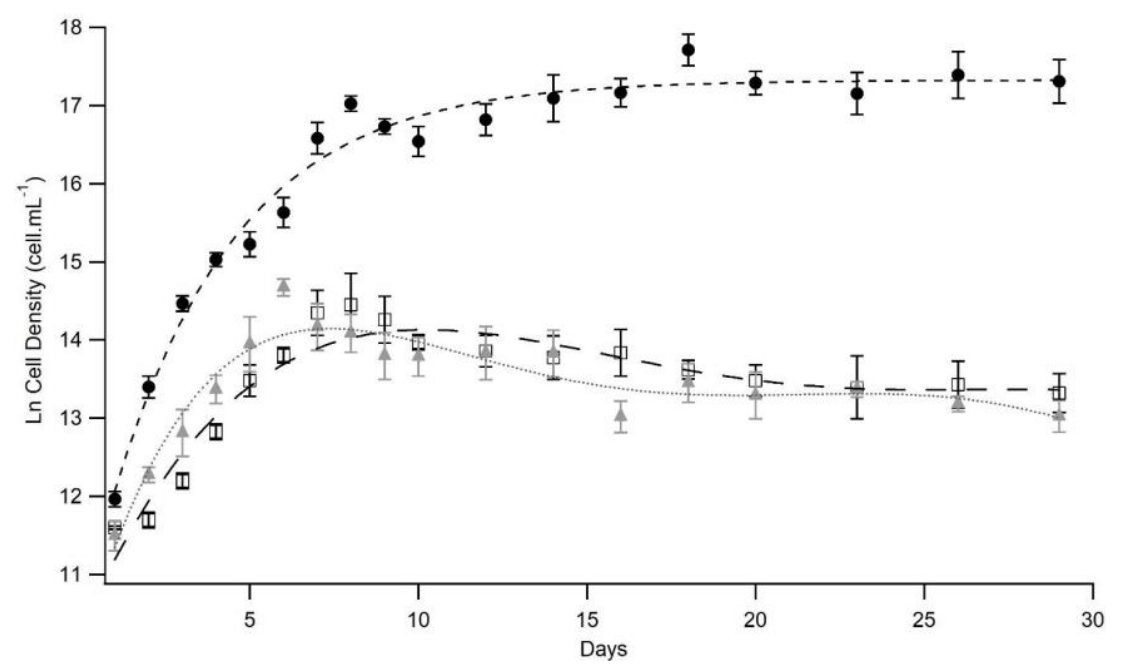

Figure 1. Comparison among the growth performance of Nostoc paludosum in the control group (•), nitrogen-absent group ( $\square$ ) and phosphorus-absent group $(\rightarrow)$ with respective trend lines and standard deviation.
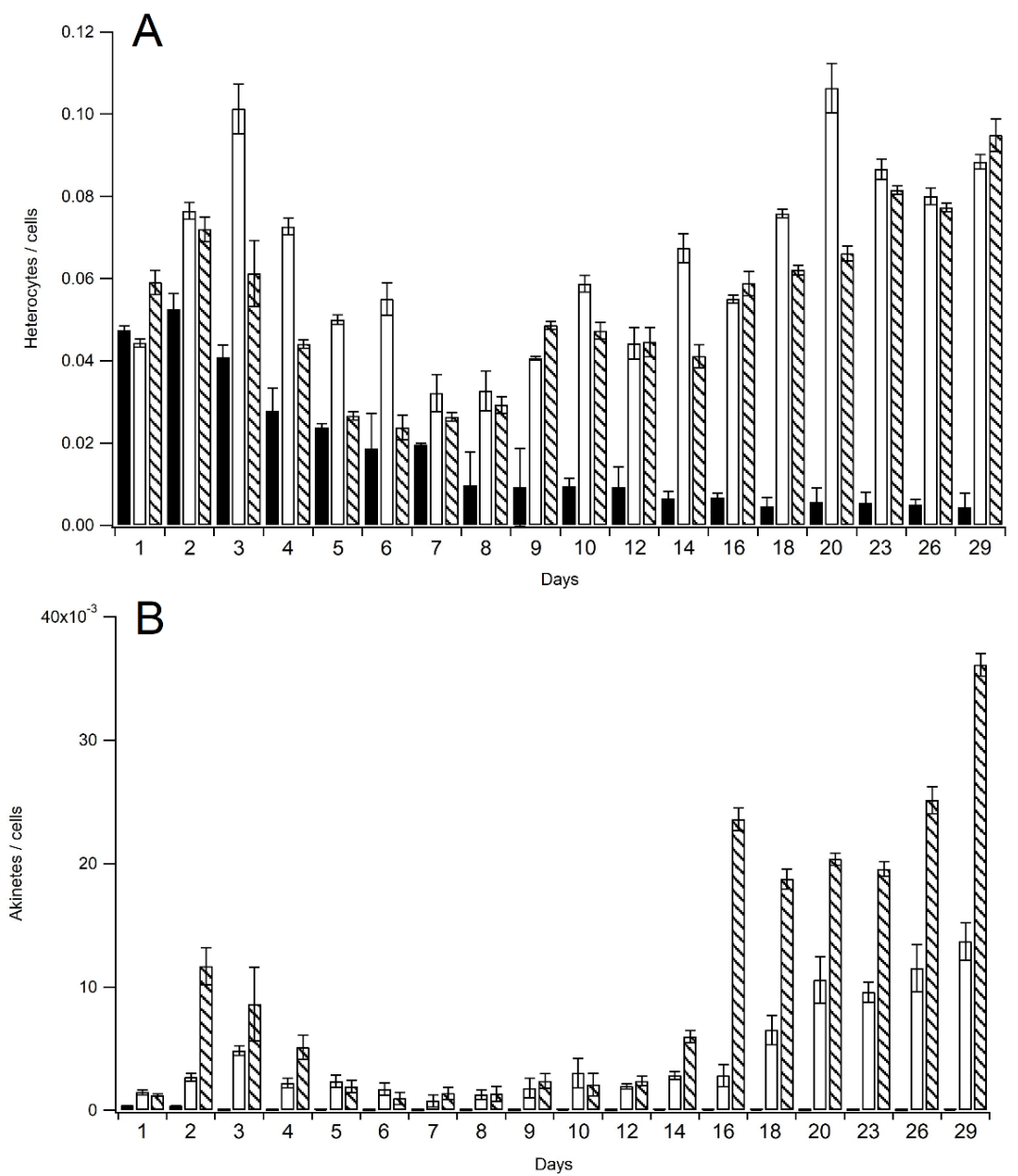

Figure 2. Average heterocyte (A) and akinete (B) production per cell of Nostoc paludosum grown in the control group ( $\mathbf{\square})$, nitrogen-absent group ( $\square$ ), and phosphorus-absent group $(\mathbb{\Xi})$, with respective standard deviation. 
As for the variation in size of vegetative cells, heterocytes and akinetes, statistically significant differences were observed between the control, nitrogen-absent and phosphorusabsent groups (Table 1). The largest and the smallest vegetative cells on all days measured were in the control group and in the phosphorus-absent group, respectively. The bigger heterocytes were found in the nitrogen-absent group, while the data for akinetes showed no statistical difference. A severe fragmentation of the trichomes was observed in the phosphorus- and nitrogen-absent groups, especially after the log phase. Differences in morphology and position of the heterocytes on the trichomes were present significantly in the nitrogen-absent group, with double and triple heterocytes occurring in between vegetative cells and terminal heterocytes at the end of some trichomes. Similarly, variations in size and position of akinetes were seen more prominently in the phosphorus-absent group.

Table 1. Mean size $(\mu \mathrm{m})$ with standard deviation (s.d.) of vegetative cells $(\mathrm{V})$, heterocytes $(\mathrm{H})$ and akinetes $(\mathrm{A})$ on days 5, 10 and 20 of the experiment for each of the three experimental groups.

\begin{tabular}{lcccc}
\hline \multirow{2}{*}{ Groups } & & Day 5 & Day 10 & Day 20 \\
\cline { 3 - 5 } & & Mean \pm s.d. & Mean \pm s.d. & Mean \pm s.d. \\
\hline \multirow{3}{*}{ Control } & V & $3.66 \pm 0.56^{* *}$ & $3.69 \pm 0.67 * *$ & $3.45 \pm 0.64 * *$ \\
& H & $4.69 \pm 0.71^{* *}$ & $4.64 \pm 0.75^{* *}$ & $4.19 \pm 0.95^{* *}$ \\
& A & $-*$ & $5.85 \pm 1.14$ & $5.32 \pm 0.33$ \\
\hline \multirow{3}{*}{ Nitrogen Absence } & V & $3.55 \pm 0.84^{* *}$ & $3.06 \pm 0.62^{* *}$ & $2.89 \pm 0.59 * *$ \\
& H & $4.96 \pm 0.83^{* *}$ & $5.09 \pm 1.03^{* *}$ & $4.42 \pm 0.79^{* *}$ \\
& A & $-*$ & $5.06 \pm 0.78$ & $5.02 \pm 0.45$ \\
\hline \multirow{3}{*}{ Phosphorus Absence } & V & $3.12 \pm 0.61 * *$ & $2.49 \pm 0.48^{* *}$ & $2.22 \pm 0.32^{* *}$ \\
& H & $4.35 \pm 1.14^{* *}$ & $3.70 \pm 0.60^{* *}$ & $3.54 \pm 0.85^{* *}$ \\
& A & $-*$ & $5.74 \pm 1.04$ & $5.26 \pm 1.11$ \\
\hline
\end{tabular}

$*(-)$ indicates no data; $* *$ Differences observed are statistically significant (ANOVA test $\mathrm{p}<0.05)$.

\subsection{Nitrogen and Phosphorus starvation effects on cell growth}

According to the growth curves, in the conditions without nutrients there was an initial growth, but at a reduced pace (smaller $\mu_{\max }$ and a duplication time almost three times longer) and with an inferior maximum cell number achieved along the growth curve when compared to the control culture. This rapid initial growth observed in all treatments can be explained by the capability of these cyanobacteria of storing phosphate as polyphosphate bodies (Lee, 2008), demonstrating that this nutrient was consumed to provide energy for the first growth event. This same strategy has already been described in the literature as a major survival factor of the genus Anabaena in low-phosphorus environments (Nalewajko and Murphy, 2001; Zapomělová et al., 2008a) and also for the Cylindrospermopsis genus (Willis et al., 2015). It seems that this reserve was consumed in the initial days of the experiment, resulting in the lowest cell production, smaller cell size and an early stationary phase in the groups with nutrient deficiencies. The maximum specific growth rates and the duplication time obtained show that for the first seven days of the experiment (the exponential phase) the nitrogen- and the phosphorus-absent populations increased much less than the control group, for which cell density at the seventh day was almost four times bigger than the other groups. The occurrence of cell division and growth in the nutrient-absent treatments proves the nutrient storage capability of the Nostoc paludosum, but their reduced rate (with a reduction of $30 \%$ in the $\mu_{\max }$ of the nutrient-absent treatments and an increment of almost 3 times at their duplication time during the log phase) in comparison to the control provides evidence as to the importance of both nutrients' presence in 
order to support the optimum growth of this cyanobacteria.

During the daily sampling of the phosphorus-absent group, tangling and fragmentation of the trichomes was observed, which was similarly seen with the nitrogen-absent group. Zapomělová et al. (2008a) discussed that phosphorus deficiency can reduce the size of the vegetative cells, generating morphospecies of Anabaena circinalis and Anabaena crassa (currently as Dolichospermum circinalis and D. crassum). There were alterations seen in trichome length, showing that the reduction of nutrients can induce fragmentation especially during the log phase, in which growth is dependent on a large number of different nutrients in the culture medium (Nalewajko and Murphy, 2001).

The growth in the nitrogen-absent group occurred at a lower rate than the control group and almost at the same rate as the phosphorus group, showing that the nutrient-starvation conditions are indeed a negative growing state when compared to normal conditions (control). Similar results were obtained in studies evaluating other species of cyanobacteria in which the absence of phosphorus caused irregular cell-membrane formation and reduced overall cell division (Chevalier et al., 2000).

\subsection{Nitrogen and Phosphorus starvation effects on heterocytes and akinetes synthesis}

As for the synthesis of heterocytes, it is noticeable that this structure was produced in all treatments, in different intensities and mainly in the stationary phase of growing, as normally happens due the decrease of nutrients in the culture. The lower rates of heterocyte per cell were recorded in the control group, which support the idea that the synthesis of this structure is related to stressful nutritional conditions (Willis et al., 2015, Guo et al., 2016). It is discussed by many researchers that nitrogen limitation is the main factor that starts the formation of heterocytes in cyanobacteria (Adams and Carr, 1981; Haselkorn et al., 1993 and Zapomělová et al., 2008b) and, while this fact was observed in this study, we add the information that the stress caused by the absence of phosphorus in the medium can also trigger the synthesis of special structures in Nostoc paludosum.

The more evident differences in morphology, size and position of the heterocytes on the trichomes were present in the nitrogen-absent group, where the heterocytes were significantly larger than those found on the other treatments. Apparently, these differences are related to the amount of nutrient dissolved in the medium, as analyzed in laboratory conditions by Zapomělová et al. (2008b), in which a great variation of the heterocyte's positions are shown. The relationship observed in this study between the absence of phosphorus and heterocyte synthesis differs from the data of Zapomělová et al. (2008b), in which it is described that this nutrient has little influence on heterocyte production.

The position of the heterocytes in the trichome was the most remarkable trace found in this study, with terminal and intercalary heterocytes being found in all treatments. The nitrogenabsent group also displayed rarer positions, such as double- and triple heterocytes and heterocytes next to akinetes. In the literature, these variations of position are related to stressful growth conditions such as the absence of vital nutrients developed in our study or also high light intensity combined with nitrogen starvation, shown in studies using Anabaena cylindrica (Adams and Carr, 1981), another species of the Nostocales order. Muro-Pastor and Hess (2012) argue that the differentiation of heterocytes is a delicate and precise intracellular process that requires optimal regulation and cell communication to properly occur. Stressful environmental conditions, such as the one created by our experiments (lack of nutrients) can cause negative effects on intracellular communication and on regulatory pathways, leading to abnormal heterocyte positioning on the trichome.

The akinete synthesis is strongly related to late phases of the growing curve, associated with the deficiency of nutrients characteristic of these stages in batch cultures. The phosphorusabsent treatment showed the higher production of akinetes. It was also in this group that most 
variations of position and morphology of akinetes were observed. Zapomělová et al. (2008b) discuss in their study that akinete production in the genus Anabaena varies with the nutritional state of the medium, altering the dimensions and form of this structure. Light seems to also play a crucial role in the synthesis of akinetes, as examined in the different light intensities experiment of this study. The significantly high values of akinetes observed in the final days of the experiment in the phosphorus-absent group clearly show the importance of this nutrient in maintaining a healthy cellular state. Therefore, the general observations regarding the effects of nutrient starvation on growth, synthesis and abnormal positioning of heterocytes and akinetes on Nostoc paludosum provide significant information about this cyanobacteria's biology.

\subsection{Light Experiment}

The growth curves show that all treatments produced similar growth trend lines, with the $100 \%$ light culture producing the higher quantities of cells, followed by the $50 \%$ light group (Figure 3). The log phase was short, followed by a stationary phase with high cell density and, after the tenth day, cell numbers decreased continuously for all treatments. A death phase was observed at the end of the experiment for all groups. The average cell number decreased with the light intensity. As for the maximum specific growth rate of each treatment, the total light treatment showed the highest value when compared to the other treatments $\left(\mu_{\max }=1.515\right.$ day $^{-1}$ for $100 \%$ light, $\mu_{\max }=0.874$ day $^{-1}$ for $50 \%$ light and $\mu_{\max }=0.689$ day $^{-1}$ for $13.5 \%$ light). All experimental treatments presented similar duplication times of approximately 4 hours $(201 \pm$ 4 minutes for $100 \%$ light, $204 \pm 9$ minutes for the $50 \%$ light and $238 \pm 14$ minutes for the $13.5 \%$ light).

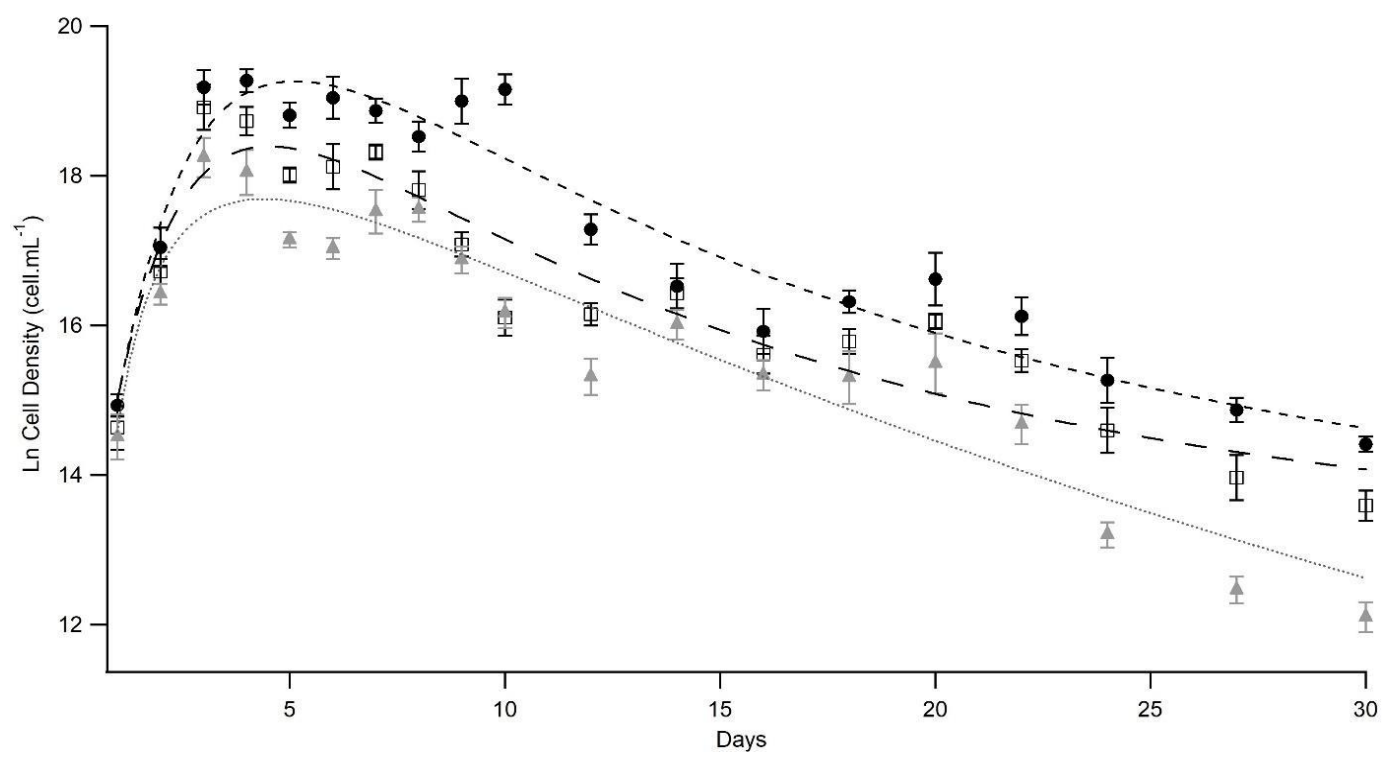

Figure 3. Comparison of the growth performance of Nostoc paludosum in the $100 \%$ / total light group $(\bullet), 50 \%$ / partial light group $(\square)$ and $13.5 \%$ / restricted light group $(\triangle)$, with respective trend lines and standard deviation.

The average heterocyte frequency per cell (Figure 4A) shows that all treatments produced small amounts of this structure during most of the experiment's duration. Only on the $24^{\text {th }}$ day and beyond was a considerable amount of heterocytes per cell registered for the severely restricted light group (13.5\%). This trend was also observed at the 50\% light group in the two final sampling points of the experiment.

The presence of akinetes (Figure 4B) only occurred significantly at the end of the experiment and only in the severely restricted light intensity (13.5\% light) group. The highest synthesis of akinetes happened on the $30^{\text {th }}$ day ( 0.08 akinete per cell or 14360 akinetes $\left.\mathrm{mL}^{-1}\right)$.

\section{IPABH}

Rev. Ambient. Água vol. 13 n. 6, e2191 - Taubaté 2018 

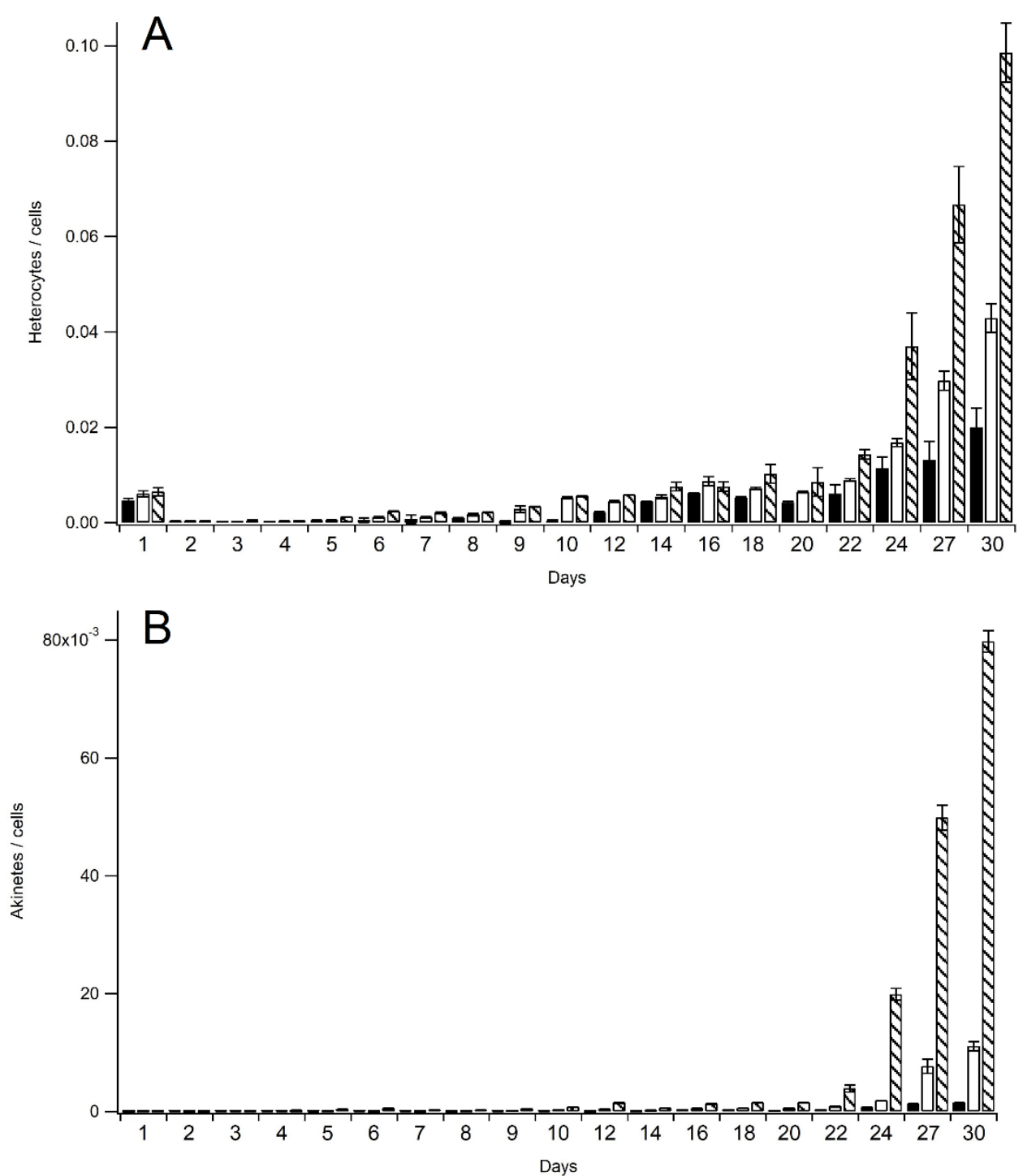

Figure 4. Average heterocyte (A) and akinete (B) production per cell of Nostoc

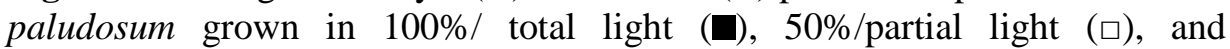
$13.5 \% /$ restricted light $(\mathbf{\nabla})$, with respective standard deviation.

Variation in the size of vegetative cells, heterocytes and akinetes was observed for each light treatment (Table 2). The only statistically significant result obtained was for the akinetes' size, with the largest occurring in the 13.5\%/restricted-light group. Vegetative cells and heterocytes data were not statistically different. Considerable fragmentation of the trichomes was observed in the restricted-light intensity (13.5\% of the total light) group, especially after the fifth day of the experiment. Differences in the morphology and position of the heterocytes on the trichomes were not observed; however, variations in the size and position of akinetes were noticed in the restricted-light group.

\subsection{Effects of light intensity on cell growth}

The higher light-restriction treatments had a slightly smaller initial yield when compared to the $100 \%$ light group during the exponential phase. When directly compared to the total light group, the $13.5 \%$ light treatment had a fourfold mean reduction in cell production, indicating a direct correlation between light intensity, cell division and, consequently, photosynthesis. It helps to explain how the cyanobacteria are capable of colonizing most of the photic zone. Even with severe light-intensity reduction, which resembles a deeper depth in the natural 
environment, the Nostoc paludosum was capable of surviving and producing high cell density. Other species of the Nostoc genera were observed to form a non-characteristic morphotype under severe luminosity reduction conditions (Lazaroff and Vishniac, 1961), returning to regular cell morphology when exposed to light again. The main hypotheses for the formation of morphotypes is that the presence of light is responsible for the synthesis of light-dependent morphogenic substances that induce normal growth and morphology. In our work. In our work, there were no significant morphologic alterations observed in any of the treatments, probably due the short duration of the experiments.

Table 2. Mean size $(\mu \mathrm{m})$ with standard deviation (s.d.) of vegetative cells $(\mathrm{V})$, heterocytes $(\mathrm{H})$ and akinetes $(\mathrm{A})$ on days 5,10 and 20 of the experiment for each of the three experimental groups.

\begin{tabular}{lcccc}
\hline \multirow{2}{*}{ Groups } & & Day 5 & Day 10 & Day 20 \\
\cline { 2 - 5 } & & Mean \pm s.d. & Mean \pm s.d. & Mean \pm s.d. \\
\hline \multirow{3}{*}{ 100\% Light } & V & $3.55 \pm 0.84$ & $3.36 \pm 0.62$ & $3.18 \pm 0.32$ \\
& H & $4.96 \pm 0.83$ & $5.09 \pm 1.03$ & $4.42 \pm 0.79$ \\
& A & $-*$ & $5.05 \pm 0.78^{* *}$ & $5.08 \pm 0.45^{* *}$ \\
\hline \multirow{3}{*}{ 50\% Light } & V & $3.24 \pm 0.61$ & $3.09 \pm 0.48$ & $2.98 \pm 0.32$ \\
& H & $4.35 \pm 1.14$ & $4.70 \pm 0.60$ & $4.34 \pm 0.85$ \\
& A & $-*$ & $5.69 \pm 1.04^{* *}$ & $5.76 \pm 1.11^{* *}$ \\
\hline \multirow{3}{*}{$13.5 \%$ Light } & V & $3.34 \pm 0.81$ & $2.89 \pm 0.36$ & $2.75 \pm 0.44$ \\
& H & $4.48 \pm 0.77$ & $4.81 \pm 0.83$ & $4.42 \pm 0.70$ \\
& A & $5.47 \pm 0.57$ & $6.24 \pm 0.89^{* *}$ & $6.39 \pm 1.01 * *$ \\
\hline
\end{tabular}

*(-) indicates no data; **Differences observed are statistically significant (ANOVA test $\mathrm{p}<0.05$ ).

Other research using Nostoc flagelliforme showed that increased light intensity (up to $200 \mu \mathrm{mol} \mathrm{m} \mathrm{m}^{-2} \mathrm{~s}^{-1}$ ) combined with the addition of $\mathrm{CO}_{2}$ enhances the yield of cell production by several times without major cell damage caused by high-light conditions (Gao and $\mathrm{Yu}, 2000$ ). However, there are other cases when reduced light intensity serves as a stimulus to growth. A comparison between the Planktothrix and Dolichospermum genus (cited as Oscillatoria and Anabaena) has showed that under 6 hours of light exposure (a short period) and low light intensity, the Planktothrix genus is benefited, growing faster and producing more cells than the Dolichospermum (Foy et al., 1976). The Dolichospermum genus is considered a dominant cyanobacteria in natural environments, which would make sense for it to be adapted to growth better under higher light intensities in order to outgrow other competitors on the phytoplankton. The Nostoc genus is not a dominant or common representative of the phytoplankton in most aquatic ecosystems, but in extreme habitats such as the polar regions or temperate climates this genus might represent a significant portion of the phytoplankton community (Vincent, 2000; Pócs, 2009). It has been shown that this genus benefits from periods of long, low-intensity light exposure, such as the ones found in colder environments. For the light cycle used in our experiment (12:12), the light intensity tested proved to be lower than necessary for optimum growth of the control group.

However, a great decline in cell density is noticeable in our experiment after the tenth day in all experimental groups. Differently from our control group of the previous experiment, this culture did not maintain its cell density for the rest of the experiment. One explanation is the self-shading effect suffered by the culture after its great density after the exponential phase, which could have greatly affected the photosynthetic capacity of the cells (Kaplan-Levy et al., 2010). Nonetheless, this effect may only partially explain this steep drop. Our decision to 
maintain the control group under the light intensity of $60.0 \pm 2.7 \mu \mathrm{mol} \mathrm{m} \mathrm{m}^{-2} \mathrm{~s}^{-1}$ may have caused some extent of stress or may have proven to be less light than the Nostoc paludosum really requires to grow ideally, as observed in the control group of the nutrient-absent experiment, which was exposed to $120 \mu \mathrm{mol} \mathrm{m} \mathrm{m}^{-2} \mathrm{~s}^{-1}$. The decision to reduce the maximum light intensity for the control group between experiments was based on many studies in the literature that claim that optimal light intensity for several Nostocales species varies from 50 to $75 \mu \mathrm{mol} \mathrm{m} \mathrm{m}^{-2} \mathrm{~s}^{-1}$ (Saker and Neilan, 2001, Moore et al., 2005; Dyble et al., 2006). Another factor that may explain the observation of the decline in cell density in all groups was the value of inoculum used in this experiment (which was 250 times larger than the inoculum of the nutrient deficiency experiment). The much larger population of cells demanded a great amount of nutrients to maintain itself, which may have become a restricting factor after the tenth day. This is supported by the fact that the cell density of the all treatments in the light experiment were higher than the density observed in the control group of the previous experiment $\left(\mu_{\max }\right.$ obtained for the $100 \%$ and 50\% light groups were higher than the maximum growth rate observed for the control group of the previous experiment, while the duplication time was similar). However, after the tenth day, the overpopulated groups in the light experiment show a continuous decline in cell numbers, whereas the control of the nutrient-absent experiment maintain the average cell number until the end of the 30-day period.

Nonetheless, the data gathered in both experiments show that Nostoc paludosum is able to grow efficiently in an interval of light intensity between 120 to less than $60 \mu \mathrm{mol} \mathrm{m} \mathrm{m}^{-2} \mathrm{~s}^{-1}$, which demonstrates its adaptability to different environmental conditions.

\subsection{Effects of light intensity on heterocyte and akinete synthesis}

According to the akinete data obtained in this study, light intensity and its effects on the ability of the cell to realize photosynthesis are the main triggers to induce the formation of akinetes. It is already known that light is essential to akinete germination. In a study of Braune (1980), irradiations of $20 \mathrm{~W} \mathrm{~m}^{-2}$ for 30-70 hours were capable of inducing germination of akinetes of Anabaena variabilis. Since light is the determinant factor to activate this structure, the lack of light is probably associated with its formation. Our results showed that under more than $85 \%$ light reduction, a culture of Nostoc paludosum produces 50 times more akinetes than when it is cultivated in a condition with no light limitations, underlining the vital role of this structure in the maintenance of this species' survival.

It is also interesting to highlight that we registered the formation of akinetes in all groups towards the end of the experiment. However, the akinetes found in the 100\% light group were significantly smaller than those found in the light-restricted treatments. An explanation for the production of akinetes in all treatments may be drawn if we consider the culture self-shading effect (Kaplan-Levy et al., 2010). The group without light restriction presented the highest cell density, which means that many of this culture's cells were probably being shaded by other cells in the Mariotte bottle, receiving less than the ideal amount of light. These shaded cells probably formed the akinetes we found on the $100 \%$ light group, enhancing our understanding that light is crucial for akinete formation.

Nonetheless, other significant akinete formation factors in cyanobacteria have already been described in the literature. The reduction of the temperature has induced the formation of akinetes in Dolichospermum spiroides and D. crassum (Li et al., 2008). The same study has also suggested that the formation of heterocytes in a large quantity also induces the production of resistance cells. Another study that evaluated the effects of temperature and light intensity in Nostoc flagelliforme has found that an increase in temperature $\left(25\right.$ to $\left.45^{\circ} \mathrm{C}\right)$ favors cell growth, whereas a reduction in light intensity diminishes the cell division rate and the synthesis of polysaccharides, essential substances to the cells' survival (Bi and $\mathrm{Hu}, 2004$ ). All of these effects are probably related to the reduction of the photosynthetic rate, which could also explain 
the results obtained for our $13.5 \%$ light treatment concerning cell numbers and expression of akinetes, demonstrating the significance of this structure for the species' survival.

Since all light treatments produced heterocytes in a similar amount and pattern during most of the experiment's duration, it can be concluded that the light intensities used in this experiment $\left(60.0,30.0\right.$ and $\left.8.1 \mu \mathrm{mol} \mathrm{m}^{-2} \mathrm{~s}^{-1}\right)$ demonstrate that light is not the main factor driving heterocyte differentiation. In the nutrient-starvation experiment, all groups were submitted to the same light intensity $\left(120.0 \mu \mathrm{mol} \mathrm{m} \mathrm{m}^{-1}\right)$ and the amount of heterocytes produced and their positions in the trichome were different between treatments, supporting the idea that the synthesis of heterocytes can be better explained by the nutritional condition of the environment. The heterocytes observed at the end of the experiment may indicate the beginning of a nutritional stress at the culture media after supporting a great cell density for more than 20 days.

Light limitation not only affects the photosynthetic capacity of the cell, but it also alters the cyanobacteria's ability to fixate nitrogen through the heterocyte. The sporulation (name given to the process of differentiation of a vegetative cell into an akinete) is related to the reduction of the activity on the heterocytes. In our analysis of the heterocyte synthesis, there was no direct relation between light restriction and production of this structure, with it being better explained in the nitrogen and phosphorus starvation experiment. However, the light limitation could have indirectly altered the functionality of the heterocytes and their capability to properly fixate nitrogen since the reduction of light creates a stressful condition to the overall photosynthetic metabolism of the cell (Zapomělová et al., 2008b). Consequently, by affecting the heterocytes, the light restriction also triggered the sporulation of the akinetes found in our experiments.

The connection between akinetes and heterocytes also seems to be related to genetic mechanisms and development factors along the life cycle of the cyanobacteria. According to Leganés et al. (1994), the hetR and hetP genes of Nostoc ellipsosporum are directly responsible for the formation of special structures. When het $R$ is blocked, there is no production of heterocytes or akinetes; however, a mutation that silences the hetP gene inhibits the synthesis of heterocytes, with the regular occurrence of akinetes. Only further morphologic and genetic studies can truly clarify the relation between these two special structures.

\section{CONCLUSIONS}

Our results showed that the nutritional deficiencies of nitrogen and phosphorus and the variation in light intensities are capable of altering the regular growth dynamics of Nostoc paludosum, with the nitrogen and phosphorus limitations and the severe light restriction of $13.5 \%$ being the most effective in reducing cell-growth rates. The absence of nutrients in the culture medium and the limitation of light reaching the cyanobacteria cells are capable of altering the morphology of vegetative cells, with an increase in fragmentation, also affecting the special structures, akinetes and heterocytes. The most evident variations in the heterocytes was observed in the nitrogen-absent group, while a similar trend happened for the akinetes in the phosphorus-absent group and in the severely restricted-light treatment, with both data being supported by other studies in the literature. Particularly for the heterocytes synthesis, we observed that illuminance did not seem to play a direct role in its formation and position on the trichome, but it is probably associated with its functionality, with nutrient concentration, specially nitrogen, as the key aspect that explains heterocyte production. That is why the restriction of this essential nutrient increased this structure's synthesis, a fact that help us understand the strategies used by heterocytous cyanobacteria to survive in extremely limiting environments, particularly related to nitrogen deficiency.

The data generated in this research broadens the understanding of some factors involved in the general growth and synthesis of heterocytes and akinetes in Nostoc paludosum, a species 
that has had few studies published about its basic biology. Our study will therefore aid future research that can further the knowledge regarding this species of cyanobacteria or the study of its applications in bioengineering.

\section{ACKNOWLEDGEMENTS}

This study was financially supported by the Research Foundation of the State of Sao Paulo, FAPESP (processs number 2010/ 50738-8) and the National Council of Technological and Scientific Development, CNPq (project number 800408/ 2011-0), both being Brazilian public organizations.

\section{REFERENCES}

ADAMS, D. G.; CARR, N. G. Heterocyte differentiation and cell division in the cyanobacterium Anabaena cylindrical: effect of high light intensity. Journal of Cell Science, v. 49, n. 1, p. 341-352, 1981.

ALLEN, M. B.; ARNON, D. I. Studies on Nitrogen-Fixing Blue-Green Algae. I. Growth and Nitrogen Fixation by Anabaena Cylindrica. Plant Physiology, v. 30, n. 4, p. 366-372, 1955 .

BI, Y. H.; HU, Z. Y. Influence of temperature, nutrients and light intensity on the growth of Nostoc flagelliforme. The Chinese Journal of Process Engineering, v. 4, n. 3, p. 249254, 2004.

BRAUNE, W. Structural aspects of akinete germination in the cyanobacterium Anabaena variabilis. Archives of Microbiology, v. 126, n. 3, p. 257-261, 1980. https://doi.org/10.1007/BF00409929

CHEVALIER, P.; PROULX, D.; LESSARD, P.; VINCENT, W. F.; DE LA NOÜE, J. Nitrogen and phosphorus removal by high latitude mat-forming cyanobacteria for potential use in tertiary wastewater treatment. Journal of Applied Phycology, v. 12, n. 2, p. 105-112, 2000. https://doi.org/10.1023/A:1008168128654

DYBLE, J.; TESTER, P. A.; LITAKER, R. W. Effects of light intensity on cylindrospermopsin production in the cyanobacterial HAB species Cylindrospermopsis raciborskii. African Journal of Marine Science, v. 28, n. 2, p. 309-312, 2006. https://doi.org/10.2989/18142320609504168

FOY, R. H.; GIBSON, C. E.; SMITH, R. V. The influence of daylength, light intensity and temperature on the growth rates of planktonic blue-green algae. British Phycological Journal, v. 11, n. 2, p. 151-163, 1976. https://doi.org/10.1080/00071617600650181

GAO, K.; YU, A. Influence of $\mathrm{CO} 2$, light and watering on growth of Nostoc flagelliforme. Journal of Applied Phycology, v. 12, n. 2, p. 185-189, 2000. https://doi.org/10.1023/A:1008123203409

GUO, L. L.; LIAO, J. Z.; SHEN, J. Y.; SHEN, Q. G. Effects of Bensulfuron-Methyl on cell morphology of A. azotica. Feb-Fresenius Environmental Bulletin, v. 2016, p. 3981, 2016.

HASELKORN, R.; LIANG, J. H.; SCAPPINO, L.; BUIKEMA, W. J. Heterocyte differentiation and nitrogen fixation in the cyanobacteria Anabaena. In: NEWTON, W. E. (Ed.). New Horizons in Nitrogen Fixation. Germany: Kluwer Academic Publishers, 1993. p. 417- 422. 
HEALEY, F. P.; HENDZEL, L. L. Indicators of phosphorus and nitrogen deficiency in five algae in culture. Journal of the Fisheries Board of Canada, v. 36, n. 11, p. 1364 -1369, 1979. https://doi.org/10.1139/f79-195

KAPLAN-LEVY, R. N.; HADAS, O.; SUMMERS, M.; RUCKER, J.; SUKENIK, A. Akinetes: dormant cells of cyanobacteria. In: CERDÀ, J. (Ed.). Dormancy and resistance in harsh environments. Germany: Springer, 2010. p. 5-27.

LAZAROFF, N.; VISHNIAC, W. The effect of light on the developmental cycle of Nostoc muscorum, a filamentous blue-green alga. Journal of General Microbiology, v. 25, n. 3, p. 365-374, 1961. https://dx.doi.org/10.1099/00221287-25-3-365

LEE, R. E. Phycology. Cambridge: Cambridge University Press, 2008. 560 p.

LEGANÉS, F.; FERNANDEZ-PIÑAS, F.; WOLK, C. P. Two mutations that block heterocytes differentiation have different effects on akinete differentiation in Nostoc ellipsosporum. Molecular Microbiology, v. 12, n. 4, p. 679-684, 1994. https://doi.org/10.1111/j.13652958.1994.tb01055.x

LI, R.; WATANABE, M.; WATANABE, M. M. Akinete formation in planktonic Anabaena spp. (Cyanobacteria) by treatment with low temperature. Journal of Phycology, v. 33, n. 4, p. 576-584, 2008. https://doi.org/10.1111/j.0022-3646.1997.00576.x

LYRA, C.; SUOMALAINEN, M.; GUGGER, C.; VEZIE, P.; SUNDMAN, L. et al. Molecular characterization of planktic cyanobacteria of Anabaena, Aphanizomenon, Microcystis and Planktothrix genera. International Journal of Systematic and Evolutionary Microbiology, v. 51, n. 2, p. 513-526, 2001. https://dx.doi.org/10.1099/00207713-51-2513

MOORE, D.; O’DONOHUE, M. A. R. K.; GARNETT, C.; CRITCHLEY, C.; SHAW, G. Factors affecting akinete differentiation in Cylindrospermopsis raciborskii (Nostocales, Cyanobacteria). Freshwater Biology, v. 50, n. 2, p. 345-352, 2005. https://doi.org/10.1111/j.1365-2427.2004.01324.x

MURO-PASTOR, A. M.; HESS, W. R. Heterocyst differentiation: from single mutants to global approaches. Trends in Microbiology, v. 20, n. 11, p. 548-557, 2012. https://doi.org/10.1016/j.tim.2012.07.005

NALEWAJKO, C.; MURPHY, T. P. Effects of temperature and availability of nitrogen and phosphorus on the abundance of Anabaena and Microcystis in Lake Biwa, Japan: an experimental approach. Limnology, v. 1, n. 1, p. 45-48, 2001. https://doi.org/10.1007/s102010170015

PANKRATOVA, E. M.; TREFILOVA, L. V.; ZYABLYKH, R. Y.; USTYUZHANIN, I. A. Cyanobacterium Nostoc paludosum Kütz as a basis for creation of agriculturally useful microbial associations by the example of bacteria of the genus. Microbiology, v. 77, n. 2, p. 228-234, 2008. https://doi.org/10.1134/S0026261708020173

PÓCS, T. Cyanobacterial crust types, as strategies for survival in extreme habitats. Acta $\begin{array}{llllllll}\text { Botanica Hungarica, } & \text { v. 51, } & \text { n. } 1, & \text { p. 147-178, }\end{array}$ https://doi.org/10.1556/ABot.51.2009.1-2.16

SAKER, M. L.; NEILAN, B. A. Varied diazotrophies, morphologies and toxicities of genetically similar isolates of Cylindrospermopsis raciborskii (Nostocales, Cyanophyceae) from northern Australia. Applied and Environmental Microbiology, v. 67, n. 4, p. 1839-1845, 2001. http://dx.doi.org/10.1128/AEM.67.4.1839-1845.2001 
SANT'ANNA, C. L.; MELCHER, S. S.; CARVALHO, M. C.; GELMEGO, M. P.; AZEVEDO, M. T. de P. Planktic Cyanobacteria from upper Tietê basin reservoirs, SP, Brazil. Brazilian Journal of Botanic, v. 30, p. 1-17, 2007. http://dx.doi.org/10.1590/S010084042007000100002

TEMINA, M.; REZANKOVA, H.; REZANKA, T.; DEMBITSKY, V. M. Diversity of the fatty acids of the Nostoc species and their statistical analysis. Microbiological Research, v. 162, n. 4, p. 308-321, 2007. https://doi.org/10.1016/j.micres.2006.01.010

TONK, L.; VISSER, P. M.; CHRISTIANSEN, G.; DITTMANN, E.; SNELDER, E. O. F. M.; WIEDNER, C. et al. The microcystin composition of the cyanobacterium Planktothrix agardhii changes toward a more toxic variant with increasing light intensity. Applied and Environmental Microbiology, v. 9, n. 71, p. 5177-5181, 2005. http://dx.doi.org/10.1128/AEM.71.9.5177-5181.2005

VINCENT, W. F. Cyanobacterial dominance in the Polar Regions. In: POTTS, M. (Ed.). The ecology of cyanobacteria. Netherlands: Springer, 2000. p. 321-340.

WILLIS, A.; ADAMS, M. P.; CHUANG, A. W.; ORR, P. T.; O’BRIEN, K. R.; BURFORD, M. A. Constitutive toxin production under various nitrogen and phosphorus regimes of three ecotypes of Cylindrospermopsis raciborskii (Woloszynska) Seenayya et Subba Raju). Harmful algae, v. 47, p. 27-34, 2015.

ZAPOMĚLOVÁ, E.; HISEM, D.; ŘEHÁKOVÁ, K; HROUZEK, P.; JEZBEROVÁ, J.; KOMÁRKOVÁ, J. et al. Experimental comparison of phenotypical plasticity and growth demands of two strains from the Anabaena circinalis/ A. crassa complex (cyanobacteria). Journal of Plankton Research, v. 30, n. 11, p. 1257-1269, 2008. https://doi.org/10.1093/plankt/fbn081

ZAPOMĚlOVÁ, E.; HROUZEK, P.; ŘEHÁKOVÁ, K.; ŠABACKÁ, M.; STIBAL, M.; CAISOVÁ, L. et al. Morphological Variability in Selected Heterocysteous Cyanobacterial Strains as a Response to Varied Temperature, Light Intensity and Medium Composition. Folia Microbiology, v. 4, n. 53, p. 333-341, 2008. https://doi.org/10.1007/s12223-008-0052-8 